\title{
Reliability and Validity of the Korean Short-form Eight-item Parkinson's Disease Questionnaire (PDQ-8)
}

\author{
Sehyun Kim ${ }^{1}$, Hye-Ja Park ${ }^{2}$, Min Jung Park ${ }^{3}$, Hyun Sook Kim ${ }^{4}$ \\ ${ }^{1}$ Professor, Graduate School, Dankook University, Jukjeon; ${ }^{2}$ Professor, College of Nursing, CHA University, Pocheon; ${ }^{3}$ Professor, Department of Nursing, \\ CHA Bundang Medical Center, CHA University, Seongnam; ${ }^{4}$ Professor, Department of Neurology, CHA Bundang Medical Center, CHA University, \\ Seongnam, Korea
}

Objectives: This study aimed to determine the reliability and validity of the Korean Parkinson's disease questionnaire (PDQ-8) using a standard shortform validation approach. Methods: This cross-sectional psychometric study evaluated 80 outpatients with PD who completed the Korean 39 -item Parkinson's disease questionnaire (PDQ-39) and PDQ-8 tools in random order. The summary index (SI) was calculated for the PDQ-39 (PDQ-39SI) and PDQ-8 (PDQ-8SI). A neurologist performed evaluations using the Hoehn and Yahr (HY) scale, unified Parkinson's disease rating scale (UPRDS motor), mini-mental state examination (MMSE), Montreal cognitive assessment (MoCA), the clinical dementia rating (CDR), and global deterioration scale (GDS). Results: The PDQ-8SI exhibited appropriate floor effect (2.5\%) and ceiling effect (1.3\%), with acceptable internal consistency reliability (Cronbach's $\alpha=0.88$ ), item-total correlations (0.48-0.77), and inter-rater reliability (Kappa coefficient $=0.53$ ). The PDQ-8 loaded one factor (Eigen value $=4.35,54.51 \%$ of the variance) and had broadly similar factor loadings (0.585-0.847). The PDQ-8 had mostly goodness of fit $(\mathrm{GFI}=0.932, \mathrm{NFI}=0.914, \mathrm{TLI}=0.973, \mathrm{IFI}=0.981$, $\mathrm{CFI}=0.981$, and RMSEA =0.056). The PDQ-8SI and PDQ-8 items exhibited good correlations with each other (all $p<0.05)$ and the PDQ-39SI $(r=0.91$, $p<0.001)$. The PDQ-8SI was correlated with levodopa dose $(r=0.28, p=0.028)$, HY score $(r=0.44, p=0.001)$, UPRDS motor $(r=0.45, p=0.007)$, MMES $(r=-0.28, p=0.047), \operatorname{MoCA}(r=-0.49, p=0.006), \operatorname{GDS}(r=0.33, p=0.025)$, and CDR ( $r=0.40, p=0.007)$, respectively. Conclusions: The PDQ-8 appears to be reliable and valid. It may be useful for quickly and easily evaluating the patient's perspectives regarding the disease's impacts, which may guide nursing practice and future research.

Key words: Parkinson's disease, Quality of life, Reliability, Validity

\section{INTRODUCTION}

Parkinson's disease (PD) is one of the three major geriatric neurodegenerative diseases and is an important issue among Koreans [1]. During the last 10 years, this disease has exhibited annual increases of $13.2 \%$ in its incidence and $21 \%$ in related healthcare costs [1,2]. Patients with PD primarily experience motor symptoms, including resting tremors, rigidity, and bradykinesia, which are caused by pathological loss or degeneration of dopaminergic neurons in the substantia nigra of the midbrain, as well as the development of neuronal Lewy bodies [3]. As the disease pro-

Corresponding author: Hye-Ja Park

120 Haeryong-ro, Pocheon 11160, Korea

Tel: +82-31-727-8886, E-mail: clara@cha.ac.kr

Received: March 4, 2020 Revised: April 3, 2020 Accepted: May 4, 2020

No potential conflict of interest relevant to this article was reported. gresses, patients also develop non-motor symptoms, including cognitive, mood, and behavioral difficulties, which significantly increase their overall disability and significantly decrease their health-related quality of life (HRQoL) [3,4].

Clinicians have access to conventional instruments for assessing PD severity and disability, such as the Hoehn and Yahr scale (HY scale) [5] and the unified Parkinson's disease rating scale [6]. However, these assessments do not provide information regarding the overall health and disease's impacts from the patient's perspective $[7,8]$. Nevertheless, HRQoL is based on the patient-reported outcomes of the physical, psy-

How to cite this article:

Kim S, Park HJ, Park MJ, Kim HS. Reliability and validity of the Korean short-form eight-item Parkinson's disease questionnaire (PDQ-8). J Health Info Stat 2020;45(2):147-156. Doi: https://doi. org/10.21032/jhis.2020.45.2.147

(C) It is identical to the Creative Commons Attribution Non-Commercial License (https://creativecommons.org/licenses/by-nc/4.0) which permit sunrestricted non-commercial use, distribution, and reproduction in any medium, provided the original work is properly cited.

(c) 2020 Journal of Health Informatics and Statistics 
chological, and social effects of their disease $[9,10]$. Importance of HRQoL assessment has increased to provide life-extending treatment and supportive care for PD patients and their families [11]. Thus, reliable and valid HRQoL measures are essential for understanding the multifaceted effects of PD and are crucial for promoting patient-centered integrated healthcare throughout the course of PD [12,13].

The 39-item Parkinson's disease questionnaire (PDQ-39) has been widely translated and validated in multiple languages as a core PD-specific HRQoL instrument $[7,8,10,14]$. This instrument evaluates the effects of PD on HRQoL based on the patient's perspectives covering mobility, activities of daily living, emotional well-being, stigma, social support, cognition, communication, and bodily discomfort [14]. However, the PDQ-39 takes some time to complete leading to the administration burden on respondents and its use has been restricted primarily to research settings or less advanced patients [8]. Therefore, to reduce respondent burden, a shorter 8-item PDQ (PDQ-8) has been constructed by selecting the most highly correlated item from each dimension of the PDQ-39 $[8,14]$. As a brief and simple measure, the PDQ- 8 is more suitable than the PDQ-39 for patients to quickly and easily complete in waiting rooms before they see their doctors or health care providers [7,8]. Implementing such a practice may improve health care provider-patient communications, patients' satisfaction, medical decision making, and eventually, patients' wellbeing [7,8]. Summary score can prove helpful in providing a guide on the overall impact of ill health as measures on questionnaires $[7,14]$. The PDQ-8 provides a summary index score of impact of PD on self-reported quality of life among PD patients [7,14]. Moreover, the PDQ-8 have been reflected the health condition including Hoehn and Yahr stage of the disease severity as a gold standard $[5,7,8,14]$, the motor function $[6,8]$, the cognitive ability $[15,16]$, and dementia $[17,18]$. Thus, the PDQ- 8 permits more economical screening the patient's health status, and it has been increasingly used in clinical trials and in everyday healthcare settings $[7,8,14]$.

Previous studies validated the PDQ-8 using the PDQ-8 items "nested" within the existing PDQ-39 data [7,14,19], despite the standard validation practice of the short form instrument should be performed by administering the instrument as an independent instrument $[8,19]$. This validation approach may influence patient responses and its psychometric properties [8], and a standard validation with the short-form measure is needed to determine whether the PDQ-8 is a useful independent instrument $[7,8,19]$. However, limited studies have been performed using a standard short-form validation approach with the PDQ-8 $[7,8,19]$. Furthermore, the Korean PDQ-8 has not been validated using a standard short-form validation approach. The present study aimed to evaluate the reliability and validity of the Korean PDQ-8 as an independent instrument for use in clinical nursing practice and research.

\section{METHODS}

\section{Setting and participants}

This cross-sectional study was conducted at a university hospital-affiliated neurology outpatient center, where PD patients visited from throughout the nation. The $\mathrm{G}^{\star}$ Power 3.1.7 program was used to estimate the optimal sample size, which was determined to be 26 patients for determining convergent validity according to the point-biserial correlation model (a two-sided test, $\alpha=0.05$, power of $1-\beta=0.80$, and effect size $p=0.50$ ) based on the previous studies $[8,20]$. To use factor analysis for determining the instrument's psychometric properties, we multiplied the 8 items (PDQ-8) or 8 scale-based dimensions (PDQ-39) by 10 to reach a number of 80. Eighty patients with neurologist-diagnosed PD were enrolled from July 2014 to June 2016. All participant were cognitively able to read and complete the questionnaires. Patients with a history of neurological diseases other than PD and psychiatric disorders were excluded based on the neurologist's decision. We administered the Korean PDQ-39 and PDQ-8 instruments to the 80 consecutive outpatients after they had provided informed consent. Thirty six (45.0\%) consecutively filled out the PDQ-8 and PDQ-39, and 44 (55.0\%) consecutively completed the PDQ-39 and PDQ-8 questionnaires in random order. To minimize missing data, a clinical research nurse checked for completeness when each patient returned his or her completed questionnaire at a counselling room. All the participants were included in this study without any dropouts. The validation procedures were based on the guidelines of the original authors and the international validation steps $[9,14]$ with the 8-dimension of the PDQ-39, the nested PDQ-8 extracted from the PDQ-39 and the independently administered PDQ-8 tools. A neurologist measured disease severity, motor function, cognitive function, and degree of dementia and then recorded the results in the electronic medical record system. This study protocol and procedures were approved by the institutional review board at Bundang CHA Medical Center (IRB No. BD2014-104). 


\section{Measurements}

\section{Demographics and clinical assessment}

The participants' demographic characteristics were collected using a self-administered questionnaire regarding age, employment status, and marital status. We also reviewed their electronic medical records to obtain data regarding clinical characteristics.

The HY scale estimates disease severity (0-5) and is the gold standard for assessing clinical outcomes [5]. The Unified Parkinson Disease Rating Scale (UPRDS) motor scale measures motor function (0-33) with higher scores indicating poorer motor function [6]. The Mini-Mental State Examination (MMSE) simply assesses the patient's cognitive function (0-30) with higher scores indicating better cognitive function [15]. The Montreal Cognitive Assessment (MoCA) sensitively screens for cognitive deficits (0-30), with higher scores indicating better cognitive function [16]. The Geriatric Depression Scale (GDS) measures the stage of dementia (1-5) with higher scores indicating poorer dementia condition [17]. The Clinical Dementia Rating scale (CDR) also measures the stage of dementia, with higher scores indicating poorer dementia ranging from CDR 0 (no dementia) to CDR 5 (terminal dementia) [18].

\section{The Parkinson's disease questionnaires (PDQ-39 and PDQ-8), and PDQ summary index}

The original author approved the use of the British English PDQ-39 and PDQ-8 and provided a user manual [14]. The use of the Korean PDQ-39 was also approved by the author [20]. The Korean PDQ-39 was developed through the steps of translation (forward translation and backward translation), cognitive debriefing by a group of specialists, a pilot test, and a transcultural adaptation test [21]. The Korean PDQ-39 exhibited the adequate content, construct, and criterion validity and reliability. Cronbach's $\alpha$ of the 8 dimension ranged from 0.70 to 0.97 in the previous study [20]. Data from the PDQ-39 or PDQ-8 can be presented in profile form as well as summarized in the PDQ-39 summary index (PDQ-39SI) or PDQ-8 summary index (PDQ-8SI) [14].

The PDQ-39 instrument consists of eight dimensions: mobility, activities of daily living, emotional well-being, stigma, social support, cognition, communication, and bodily discomfort. All items are scored from 0 (never) to 4 (always), and each dimension is transformed using a scale from 0 (no problem) to 100 (maximum difficulty). The PDQ-39 summary index (PDQ-39SI) is calculated by summing the 8-dimension scores and then standardizing the score on a scale of $0-100$, with lower scores indicating better HRQoL [14] (Table 1).

The PDQ-8 includes eight specific items selected based on the strongest correlations for the eight dimensions of the PDQ-39. The eight items are scored from 0 (never) to 4 (always), and then a summary index of the PDQ-8 (PDQ-8SI) is calculated based on the eight scores using a standardized scale (0-100), with lower scores indicating better HRQoL [14] (Table 1).

\section{Data analysis}

All analyses were performed using IBM SPSS 23.0 software (IBM Corp., Armonk, NY, USA) and AMOS 24 software (IBM Corp., Armonk, NY, USA).

(1) Data normality was determined using the Kolmogorov-Smirnov test.

(2) Differences in the mean scores between the PDQ-39SI, the nested PDQ-8SI, and the independent PDQ-8SI were analyzed using the Kruskal-Wallis test with Bonferroni's method for multiple comparisons.

(3) Floor and ceiling effects were examined based on the response ranges and distributions for each item.

(4) Internal consistency reliability was assessed using Cronbach's $\alpha$ and the item-total correlations. The inter-rater reliability was evaluated using the Kappa coefficient between the nested PDQ-8 items and the independent PDQ-8 items.

(5) Exploratory and confirmatory factor analyses were used to evaluate construct validity.

(6) For convergent validity, the Spearman's correlation analysis was performed to evaluate the relationship among the independent PDQ-8 items, as well as with the PDQ-8SI and PDQ-39SI.

(7) For the criterion validity, the Spearman's correlation analysis was used to evaluate the relationship among the independent PDQ8SI, levodopa dose, HY stage, UPRDS III, MMSE, MoCA, GDS, and CDR scores.

\section{RESULTS}

\section{Demographics and clinical assessment}

The mean age was $67.55 \pm 9.31$ years and 51 patients $(63.7 \%)$ had an onset age of $\geq 65$ years. Female accounted for 49 (61.2\%). The mean disease duration was $14.18 \pm 28.65$ months. The mean levodopa dose was 
Table 1. The Parkinson's disease questionnaire: The PDQ-39, PDQ-8, and PDQ summary index

\begin{tabular}{|c|c|c|c|}
\hline Dimensions & PDQ-39 items (Nested PDQ-8 items ${ }^{1}$ ) & Score & PDQ-8 items \\
\hline Mobility (10 items) & $\begin{array}{l}\text { Q1. Had difficulty doing leisure activity } \\
\text { Q2. Had difficulty looking after your home } \\
\text { Q3. Had difficulty carrying bags of shopping } \\
\text { Q4. Had problems walking half a mile } \\
\text { Q5. Had problems walking } 100 \text { yards } \\
\text { Q6. Had problems getting around the house } \\
\text { Q7. Had problems getting around in public places' } \\
\text { Q8. Needed to be accompanied when out } \\
\text { Q9. Frightened or worried about falling in public } \\
\text { Q10. Been confined to the house more than liked }\end{array}$ & Sum scores of Q1-Q10/(4×10)×100 & (Q1) \\
\hline $\begin{array}{l}\text { Activities daily living } \\
\text { ( } 6 \text { items) }\end{array}$ & $\begin{array}{l}\text { Q11. Had difficulty washing yourself } \\
\text { Q12. Had difficulty dressing yourself' } \\
\text { Q13. Had problems doing up buttons or laces } \\
\text { Q14. Had problems writing clearly } \\
\text { Q15. Had difficulty cutting up food } \\
\text { Q16. Had difficulty holding a cup }\end{array}$ & Sum scores of Q11-Q16/(4×6)×100 & (Q2) \\
\hline $\begin{array}{l}\text { Emotional } \\
\text { well-being (6 items) }\end{array}$ & $\begin{array}{l}\text { Q17. Felt depressed } \\
\text { Q18. Felt isolated and lonely } \\
\text { Q19. Felt weepy or tearful } \\
\text { Q20. Felt angry or bitter } \\
\text { Q21. Felt anxious } \\
\text { Q22. Felt worried about the future }\end{array}$ & Sum scores of Q17-Q22/(4×6)×100 & (Q3) \\
\hline Stigma (4 items) & $\begin{array}{l}\text { Q23. Felt you had to conceal PD } \\
\text { Q24. Avoided eating or drinking in public } \\
\text { Q25. Felt embarrassed by having PD' } \\
\text { Q26. Felt worried by other's reaction to you }\end{array}$ & Sum scores of Q23-Q26/(4×4)×100 & (Q8) \\
\hline $\begin{array}{l}\text { Social support } \\
\text { (3 items) }\end{array}$ & $\begin{array}{l}\text { Q27. Had problems with close relationships }{ }^{1} \\
\text { Q28. Not had support from spouse or partner } \\
\text { Q29. Not had support from friends or family }\end{array}$ & Sum scores of Q27-Q29/(4×3)×100 & (Q4) \\
\hline Cognitions (4 items) & $\begin{array}{l}\text { Q30. Unexpectedly fallen asleep during day } \\
\text { Q31. Had problems with concentration' } \\
\text { Q32. Felt your memory was bad } \\
\text { Q33. Had distressing dreams or hallucinations }\end{array}$ & Sum scores of Q30-Q33/(4×4)×100 & (Q5) \\
\hline $\begin{array}{l}\text { Communication } \\
\text { (3 items) }\end{array}$ & $\begin{array}{l}\text { Q34. Had difficulty with speech } \\
\text { Q35. Felt unable to communicate properly } \\
\text { Q36. Felt ignored by people }\end{array}$ & Sum scores of Q34-Q36/(4×3)×100 & (Q6) \\
\hline Bodily pain (3 items) & $\begin{array}{l}\text { Q37. Had painful muscle cramps or spasms }{ }^{1} \\
\text { Q38. Had aches and pains } \\
\text { Q39. Felt unpleasantly hot or cold }\end{array}$ & Sum scores of Q37-Q39/(4×3)×100 & (Q7) \\
\hline SI & & PDQ-39SI & PDQ-8SI \\
\hline Range (0-100) & $\begin{array}{l}0=\text { never, } 1=\text { occasionally, } 2=\text { sometimes, } 3=\text { often, } 4=\text { always } \\
\text { Each item is calculated as a scale from } 0 \text { to } 100\end{array}$ & & \\
\hline
\end{tabular}

$\mathrm{SI}$, summary index; PDQ, Parkinson's disease questionnaire.

PDQ-39SI = sum of 8 dimension scores/8; PDQ-8SI = sum of 8 item scores $/ 8$.

${ }^{1} T$ The UK english version of the PDQ-39, PDQ-8, and PDQ summary index was developed by Jenkinson et al. [14].

$370.24 \pm 258.25 \mathrm{mg}$. The mean scores for the clinical indices were $1.56 \pm$

1.14 for the Hoehn and Yahr staging score, $25.74 \pm 17.10$ for the UPDRS motor, $25.54 \pm 3.16$ for the MMSE, $18.00 \pm 8.22$ for the MoCA, $2.67 \pm 1.17$ for the GDS, and $0.93 \pm 1.17$ for the CDR (Table 2).

\section{Floor and ceiling effects, and reliability}

The PDQ-8SI exhibited the appropriate response ranges and distributions for each item, with a $2.5 \%$ floor effect and a $1.3 \%$ ceiling effect. The internal consistency reliability of the independent PDQ-8 was good 
Table 2. Demographics and clinical assessment $(n=80)$

\begin{tabular}{llc}
\hline Characteristics & Categories & Mean \pm SD or $\mathrm{n}(\%)$ \\
\hline Sociodemographic & & \\
Age $(\mathrm{y})$ & & $67.55 \pm 9.31$ \\
Onset age & $<65$ & $29(36.3)$ \\
& $\geq 65$ & $51(63.7)$ \\
Sex & Male & $31(38.8)$ \\
& Female & $49(61.2)$ \\
Employment status & Employed & $12(15.0)$ \\
& Unemployed & $68(85.0)$ \\
Spouse & Yes & $51(63.7)$ \\
& No & $29(36.3)$ \\
Clinical indices & & \\
Duration of disease (mon) & & $14.18 \pm 28.65$ \\
Levodopa dose $($ mg) $(n=63)$ & & $370.24 \pm 258.25$ \\
Hoehn \& Yahr staging score $(n=51)$ & & $1.56 \pm 1.14$ \\
UPDRS motor $(n=34)$ & & $25.74 \pm 17.10$ \\
MMES $(n=50)$ & & $25.54 \pm 3.16$ \\
MoCA $(n=31)$ & & $18.00 \pm 8.22$ \\
GDS $(n=46)$ & & $2.67 \pm 1.17$ \\
CDR $(n=44)$ & & $0.93 \pm 0.96$ \\
\hline
\end{tabular}

SD, standard deviation; UPDRS, unified Parkinson's disease rating scale; MMES, mini-mental state examination; MoCA, Montreal cognitive assessment; GDS, global deterioration scale; CDR, clinical dementia rating; $\mathrm{PDQ}$, Parkinson's disease questionnaire.
(Cronbach's $\alpha=0.88$ ). The item-total correlations ranged from 0.48 to 0.77 , with 0.53 inter-rater reliability (Kappa coefficient) between the independent and nested PDQ- 8 versions $(p<0.001)$. Cronbach's $\alpha$ of the PDQ-39 was 0.97. Cronbach's $\alpha$ of the 8 dimensions in the PDQ-39 ranged from 0.72 to 0.94 (Table 3).

\section{Content validity}

The conceptual equivalence and consistency between the British English PDQ-8 and Korean PDQ-8 instrument was evaluated by two neurology nursing specialists, a nursing professor, and a neurologist. The content validity index (CVI) was acceptable $(\mathrm{CVI}=0.95)$.

\section{Construct validity}

The means for the independent PDQ-8 items were generally similar to the means for the 8 dimensions in the PDQ-39 and the nested PDQ8 , except for the "activities of daily living" item $(p=0.047)$ (Table 4$)$.

The independent PDQ- 8 was loaded on one factor (Eigen value $=4.35$, $54.51 \%$ of the variance), with broadly similar factor loadings ( $0.585-$ 0.847). The independent PDQ-8 had mostly goodness of fit $(\mathrm{GFI}=0.932$,

Table 3. Means, floor effect, ceiling effect, and reliability ( $n=80$ )

\begin{tabular}{|c|c|c|c|c|c|c|c|c|c|c|c|}
\hline \multirow{2}{*}{$\begin{array}{l}\text { Dimensions } \\
\text { (Item number of PDQ-8) }\end{array}$} & \multicolumn{3}{|c|}{ Mean $\pm S D$} & \multirow[b]{2}{*}{$\chi^{2}$} & \multirow[b]{2}{*}{$p$} & \multicolumn{3}{|c|}{ Cronbach's $\alpha$} & \multicolumn{3}{|c|}{ Item-total-correlation } \\
\hline & PDQ-39 & $\begin{array}{l}\text { Nested } \\
\text { PDQ-8 }\end{array}$ & $\begin{array}{l}\text { Independent } \\
\text { PDQ-8 }\end{array}$ & & & PDQ-39 & $\begin{array}{l}\text { Nested } \\
\text { PDQ-8 }\end{array}$ & $\begin{array}{l}\text { Independent } \\
\text { PDQ-8 }\end{array}$ & PDQ-39 & $\begin{array}{l}\text { Nested } \\
\text { PDQ-8 }\end{array}$ & $\begin{array}{l}\text { Independent } \\
\text { PDQ-8 }\end{array}$ \\
\hline & & & & & & 0.97 & 0.86 & 0.88 & & & \\
\hline Mobility (Q1) & $46.53 \pm 30.19$ & $46.25 \pm 36.26$ & $41.56 \pm 34.21$ & 1.16 & 0.560 & 0.94 & & & 0.75 & 0.6 & 0.61 \\
\hline Activities of daily living (Q2) & $39.22 \pm 30.86^{a}$ & $32.19 \pm 37.14^{b}$ & $35.63 \pm 36.84^{a}$ & 6.10 & 0.047 & 0.92 & & & 0.75 & 0.72 & 0.73 \\
\hline Emotional well-being (Q3) & $41.61 \pm 25.77$ & $42.82 \pm 29.55$ & $40.00 \pm 28.57$ & 0.44 & 0.802 & 0.93 & & & 0.7 & 0.58 & 0.48 \\
\hline Social support (Q4) & $21.25 \pm 22.26$ & $24.06 \pm 29.08$ & $24.38 \pm 32.80$ & 0.94 & 0.626 & 0.81 & & & 0.76 & 0.76 & 0.77 \\
\hline Cognitions (Q5) & $40.73 \pm 24.77$ & $39.06 \pm 32.03$ & $36.88 \pm 33.51$ & 1.35 & 0.509 & 0.72 & & & 0.59 & 0.53 & 0.62 \\
\hline Communication (Q6) & $23.44 \pm 24.42$ & $23.13 \pm 27.78$ & $23.13 \pm 29.97$ & 1.37 & 0.505 & 0.82 & & & 0.76 & 0.57 & 0.72 \\
\hline Bodily pain (Q7) & $33.02 \pm 25.45$ & $38.44 \pm 30.28$ & $40.94 \pm 30.87$ & 2.93 & 0.231 & 0.77 & & & 0.69 & 0.48 & 0.48 \\
\hline Stigma (Q8) & $25.52 \pm 24.96$ & $27.50 \pm 28.01$ & $27.81 \pm 30.55$ & 0.05 & 0.976 & 0.84 & & & 0.64 & 0.66 & 0.77 \\
\hline Summary index (SI) & $33.92 \pm 24.40$ & $34.18 \pm 22.44$ & $33.79 \pm 23.65$ & 0.19 & 0.908 & & & & & & \\
\hline$\%$ Floor & 1.3 & 2.5 & 2.5 & & & & & & & & \\
\hline$\%$ Ceiling & 1.3 & 1.3 & 1.3 & & & & & & & & \\
\hline Kappa coefficient & & & & & & & & & & $0.53(p<c$ & $0.001)$ \\
\hline
\end{tabular}

SD, standard deviation; PDQ, Parkinson's disease questionnaire.

$\chi^{2}$ by Kruskal-Wallis test.

Summary index $=$ sum of 8 dimension or item scores $/ 8$.

PDQ-8 items: Q1. Had problems getting around in public places? (mobility), Q2. Had difficulty dressing yourself? (activities of daily living), Q3. Felt depressed? (emotional well-being), Q4. Had problems with close relationships? (social support), Q5. Had problems with concentration? (cognition), Q6. Felt unable to communicate properly? (communication), Q7. Had painful muscle cramps or spasms? (bodily pain), Q8. Felt embarrassed by having PD? (stigma).

Kappa coefficient between the nested PDQ-8 items and the independent PDQ-8 items.

a, bonferroni multiple comparisons, the same letter are not statistically significant. 
Table 4. Construct validity based on the exploratory and confirmatory factor analyses $(n=80)$

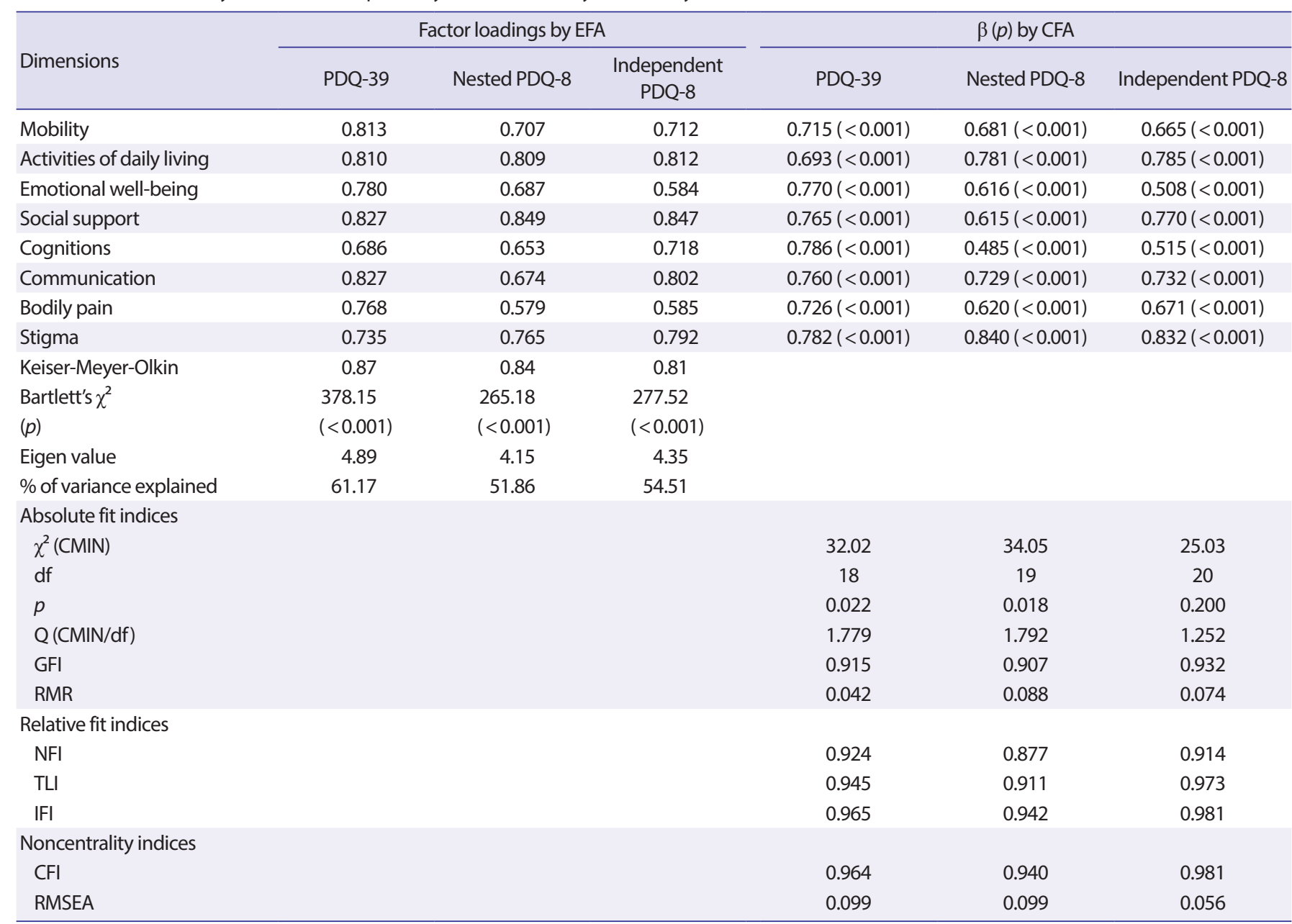

PDQ, Parkinson's disease questionnaire; EFA, exploratory factor analysis; CFA, confirmatory factor analysis; CMIN, minimum chi-square; df, degree of freedom; Q, normed chi-square; GFI, goodness of fit index; NFI, normed fit index; RMR, root mean square residual; TLI, Tucker-Lewis index, non-normed fit index; IFI, incremental fit index; CFI, comparative fit index; RMSEA, root mean square error of approximation.

$\mathrm{NFI}=0.914, \mathrm{TLI}=0.973, \mathrm{IFI}=0.981, \mathrm{CFI}=0.981$, and $\mathrm{RMSEA}=0.056)$

(Table 4).

\section{Convergent validity and criterion validity}

For convergent validity, the eight items of the independent PDQ-8 were correlated with each other (all $p<0.05$ ), as well as between the independent PDQ-8SI and PDQ-39SI scores $(r=0.91, p<0.001)$ (Table 5).

For criterion validity, the independent PDQ-8SI was correlated with the levodopa dose $(\mathrm{r}=0.28, p=0.028)$ and the HY score $(\mathrm{r}=0.44, p=$ 0.001). The independent PDQ-8SI was correlated with the scores for UPRDS motor ( $\mathrm{r}=0.45, p=0.007)$, MMES ( $\mathrm{r}=-0.28, p=0.047)$, MoCA $(\mathrm{r}=-0.49, p=0.006)$, GDS $(\mathrm{r}=0.33, p=0.025)$, and CDR $(\mathrm{r}=0.40, p=$ 0.007 ) (Table 5).

\section{DISCUSSION}

Assessment of health-related quality of life (HRQOL) is essential in developing and promoting best practices for Parkinson's disease (PD) care $[8,10]$. The 8 -item Parkinson's disease questionnaire (PDQ-8) provides a global measure of health and is accurately representative of the parent 39-item PDQ (PDQ-39) [7,14,19]. Two methods were used for the linguistic validation and cross-cultural adaptation of the PDQ-8 $[8,14,20-23]$. The first one is to use the 8 items derived from the existing PDQ-39 data [7,14,19]. The other is to standard validation practice to independently administer the short-form questionnaire to respondents [8,21-23].

In this study, the floor and ceiling effects were both judged appropri- 


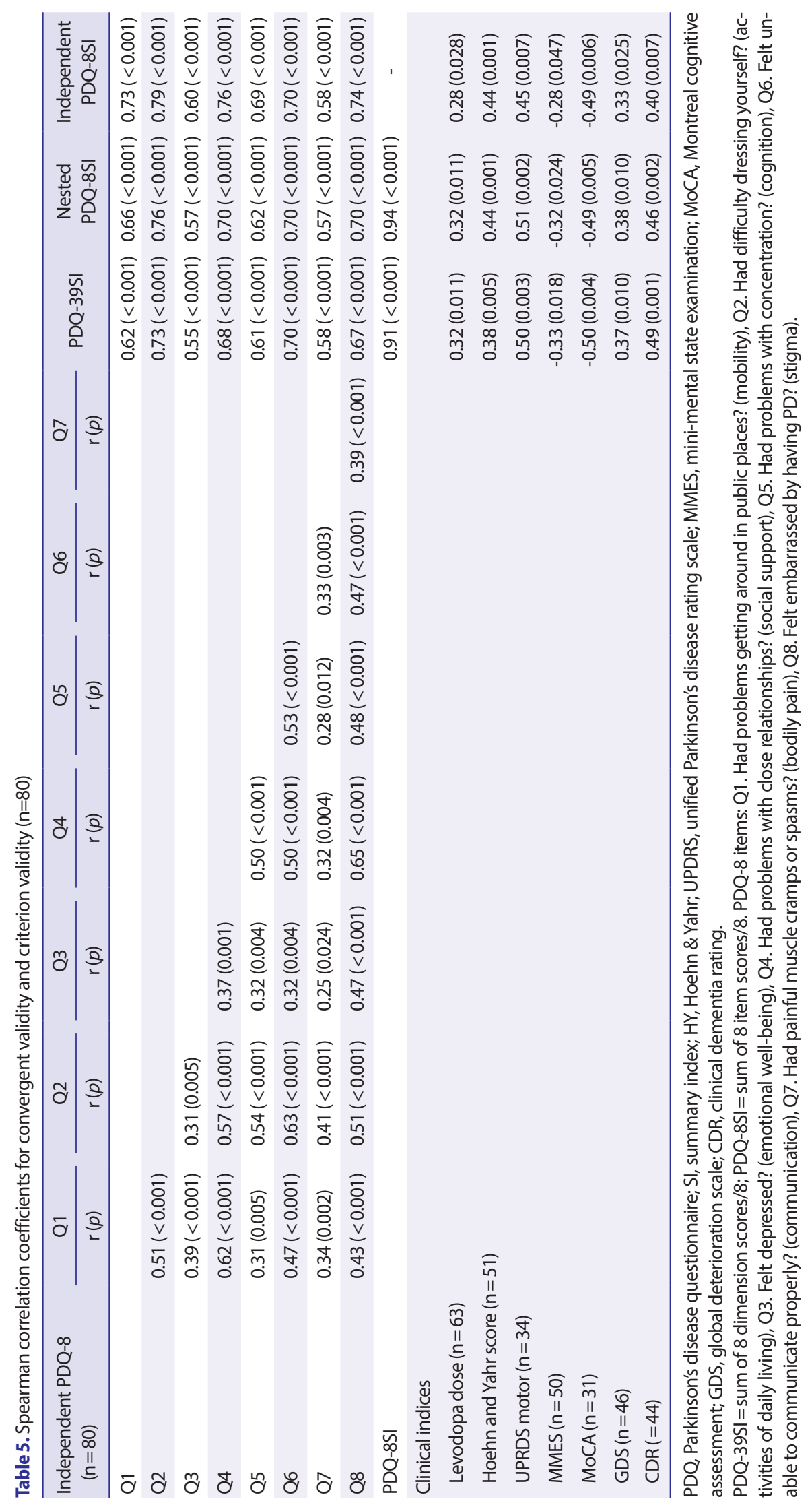


ate based on an acceptable setting points of $<20 \%$ [24], as well as findings from previous studies [8,20-23]. The internal consistency reliability should be evaluated for measuring the strength of agreement between repeated measures [9]. In this study, the independent PDQ-8 revealed acceptable internal consistency reliability $(\alpha=0.88)$ and the item-total correlations (0.48-0.73) based on the acceptable points of Cronbach's $\alpha$ of $\geq 0.7$ and the item-total correlation coefficient of $\geq 0.20$ [9]. This result may be supported by the consistent previous reports $[8,14,19,21-23]$. The Kappa coefficient demonstrated a moderate inter-rater reliability between the independent and nested PDQ- 8 instruments. This result contrasts with the outstanding Kappa coefficient of 0.983 from a previous study of 114 PD patients [22]. The discrepancy may indicate a disagreement in patient responses between the nested and independent PDQ-8 findings (the lower activities of daily living (ADL) score in the nested PDQ-8 relative to in the independent PDQ-8) $[7,8,19]$. However, the Korean PDQ- 8 is a reliable and reproducible independent instrument.

The data quality for HRQoL depends on the completeness of scalelevel and item-level data [10]. The present study completely collected the PDQ-39 and the PDQ-8 items, and the mean scores for the PDQ-8SI and PDQ-39SI were similar to the scores from a multi-national study involving America, Canada, Japan, Italy, Spain [19], and Korea [20]. The independent PDQ-8 had an one-dimensional construct with acceptable factor loadings ( $\geq 0.40)$ [9], as well as previous reports [8,19,22]. In the confirmatory factor analysis, the independent PDQ-8 had no discrepancy between the sample and fitted covariance matrices based on the $\chi^{2}$ result $(p>0.05)$ and the model Q $(\mathrm{CMIN} / \mathrm{df}<2.0)$ for a good fit. The independent PDQ-8 had a GFI of 0.932 , which suggests the appropriate proportion of variance accounted for by the estimated population covariance. However, the RMR value was barely appropriate (0.074) based on recommended cut-offs of $<0.05$ for the best fit point and $<0.08$ for a good fit point. In contrast, the RMR of the nested PDQ- 8 did not meet the good fit point (0.088), despite the RMR of the PDQ-39 being considered excellent (0.042). The relative fit indices (NFI, TLI, IFI) were acceptable based on the conventional cut point of $\geq 0.9, \mathrm{CFI} \geq 0.9$, and RM$\mathrm{SEA}<0.08$, which means all measured variables are uncorrelated. In this context, the Korean PDQ-8 has a one-dimensional construct and appears to be valid.

The eight items of the Korean PDQ-8 were correlated with each other as well as with the PDQ-39SI, the nested PDQ-8SI, and the independent PDQ-8SI, based on a minimum acceptable convergent validity value of
0.4 [9]. This result indicates that the independent Korean PDQ- 8 has good convergent validity.

The Korean PDQ-8SI was correlated with HY staging score and UPRDS motor score as clinical gold standards, although all the participants did not complete those measurements [8,14,21-23]. Even mild cognitive impairment associated with Parkinson's disease (PD) is a risk factor for the development of dementia and HRQoL deterioration, which highlights the importance of early identification of mild cognitive impairment in PD $[3,11,12]$. The independent PDQ-8SI was also correlated with cognitive function based on the MMSE [15] and MoCA scores [16], and dementia stage based on the GDS [17] and CDR [18]. Therefore, the independent Korean PDQ-8 appears to have good criterion validity. These findings may help nurses assess overall health based on physical, emotional, cognition, and social aspects. Furthermore, the assessment is relatively rapid (5-10 $\mathrm{min}$ ) and may facilitate the best possible care.

The present study has several limitations that warrant consideration. First, although the study was performed with a sample of PD patients who visited a single university hospital from throughout the nation, the findings may not necessarily generalize to other regions or populations. Second, the sample size $(n=80)$ is considered barely adequate for comparing the psychometric properties between the PDQ-39 and the PDQ8 , despite the use of scale-level or item-parceling factor analysis for the PDQ-39. Third, the present study enrolled patients with relatively mild disease severity, which is associated with a risk of bias, therefore future studies are needed to test this issue in a larger and more diverse group of patients with PD.

\section{CONCLUSION}

The results of the present study suggest that the independent Korean PDQ-8 may be a reliable and valid instrument for evaluating HRQoL among PD patients. This tool may be useful for simply and rapidly assessing the effects of PD on patients' lives, based on their perspective rather than a clinical assessment, which may help guide everyday nursing practice and PD-related research.

\section{ORCID}

Kim Sehyun https://orcid.org/0000-0002-1931-7169

Hye-Ja Park https://orcid.org/0000-0002-8923-2611 


\section{REFERENCES}

1. Kim JS, Baik JS, Kim SJ, Cho JW, Koh SB, Park KW, et al. Current status and future of Parkinson's disease Korea. Public Health Weekly Report 2018;11(31):1012-1019 (Korean).

2. Lee SH, Lee SJ, Kim YJ. Region-based analysis of prevalence and incidence of Parkinson's disease: analysis of the national sample cohort in South Korea. J Clin Neurol 2018;14(4):478-486. DOI: 10.3988/jcn.2018. 14.4.478

3. Jankovic J, Tolosa E. Parkinson's disease and movement disorders. 5th ed. Philadelphia: Lippincott Willams and Wilkins; 2007.

4. Klietz M, Tulke A, Müschen LH, Paracka L, Schrader C, Dressler DW, et al. Impaired quality of life and need for palliative care in a German cohort of advanced Parkinson's disease patients. Front Neurol 2018;9:

120. DOI: $10.3389 /$ fneur.2018.00120

5. Hoehn MM, Yahr MD. Parkinsonism: onset, progression and mortality. Neurol 1967;17(5):427-442. DOI: 10.1212/wnl.17.5.427

6. Goetz CG, Tilley BC, Shaftman SR, Stebbins GT, Fahn S, MartinezMartin P, et al. Movement disorder society-sponsored revision of the unified Parkinson's disease rating scale (MDS-UPDRS): scale presentation and clinimetric testing results. Mov Disord 2008;23(15):21292170. DOI: $10.1002 / \mathrm{mds} .22340$

7. Jenkinson C, Clarke C, Gray R, Hewitson P, Ives N, Morley D, et al. Comparing results from long and short form versions of the Parkinson's disease questionnaire in a longitudinal study. Parkinsonism Relat Disord 2015;21(11):1312-1316. DOI: 10.1016/j.parkreldis.2015.09.008

8. Tan LC, Lau PN, Au WL, Luo N. Validation of PDQ-8 as an independent instrument in English and Chinese. J Neurol Sci 2007;255(1-2): 77-80. DOI: 10.1016/j.jns.2007.01.072

9. Fayers PM, Machin M. Quality of life: the assessment, analysis, and interpretation of patient-related outcomes (2nd ed.). Chichester, England: John Wiley and Sons; 2007.

10. Martinez-Martin P, Kurtis MM. Health-related quality of life as an outcome variable in Parkinson's disease. Ther Adv Neurol Disord 2012; 5(2):105-117. DOI: $10.1177 / 1756285611431974$

11. Kang MY, Ellis-Hill C. How do people live life successfully with Parkinson's disease?. J Clin Nurs 2015;24(15-16):2314-2322. DOI: 10. 1111/jocn.12819

12. Eggers C, Dano R, Schill J, Fink GR, Timmermann L, Voltz R, et al. Access to end-of life Parkinson's disease patients through patient-cen- tered integrated healthcare. Front Neurol 2018;30(9):627. DOI: 10.3389/ fneur.2018.00627

13. Gopalakrishna A, Alexander SA. Understanding Parkinson disease: a complex and multifaceted illness. J Neurosci Nurs 2015;47(6):320-326. DOI: $10.1097 / J N N .0000000000000162$

14. Jenkinson C, Fitzpatric, R, Peto V. The Parkinson's disease questionnaire: user manual for the PDQ-39, PDQ-8 and PDQ summary index. Oxford: University of Oxford Health Services Research Unit; 1998.

15. Folstein MF, Folstein SE, McHugh PR. "Mini-mental state”. A practical method for grading the cognitive state of patients for the clinician. J Psychiatr Res 1975;12(3):189-198. DOI: 10.1016/0022-3956(75)90026-6 16. Nasreddine ZS, Phillips NA, Bédirian V, Charbonneau S, Whitehead V, Collin I, et al. The montreal cognitive assessment, MoCA: a brief screening tool for mild cognitive impairment. J Am Geriatr Soc 2005;53(4): 695-699. DOI: 10.1111/j.1532-5415.2005.53221.x

17. Choi SH, Na DL, Lee BH, Hahm DS, Jeong JH, Jeong Y, et al. The validity of the Korean version of global deterioration scale. J Korean Neurol Assoc 2002;20(6):612-617 (Korean).

18. Choi SH, Na DL, Lee BH, Hahm JH, Jeong Y, Yoon SJ, et al. Estimating the validity of the Korean version of expanded clinical dementia rating (CDR) scale. J Korean Neurol Assoc 2001;19(6):585-591 (Korean).

19. Jenkinson C, Fitzpatrick R. Cross-cultural evaluation of the short form 8-item Parkinson's disease questionnaire (PDQ-8): results from America, Canada, Japan, Italy and Spain. Parkinsonism Relat Disord 2007;13(1):22-28. DOI: 10.1016/j.parkreldis.2006.06.006

20. Park HJ, Sohng KY, Kim S. Validation of the Korean version of the 39item Parkinson's disease questionnaire (PDQ-39). Asian Nurs Res 2014;8(1):64-74. DOI: 10.1016/j.anr.2014.02.004

21. Franchignoni F, Giordano A, Ferriero G. Rasch analysis of the short form 8-item Parkinson's disease questionnaire (PDQ-8). Qual Life Res 2008;17(4):541-548. DOI: 10.1007/s11136-008-9341-6

22. Fereshtehnejad SM, Naderi N, Rahmani A, Shahidi GA, Delbari A, Lökk J. Psychometric study of the Persian short-form eight-item Parkinson's disease questionnaire (PDQ-8) to evaluate health related quality of life (HRQoL). Health Qual Life Outcomes 2014;12:78. DOI: $10.1186 / 1477-7525-12-78$

23. Kahraman T, Genç A, Söke F, GÖz E, Çolakoğlu BD, Keskįnoğlu P. Validity and reliability of the Turkish version of the 8-item Parkinson's disease questionnaire. Noro Psikiyatr Ars 2018;55(4):337-340. DOI: 10.5152/npa.2017.19343 
24. Hagell P, Whalley D, McKenna SP, Lindvall O. Health status measurement in Parkinson's disease: validity of the PDQ-39 and Nottingham health profile. Mov Disord 2003;18(7):773-783. DOI: 10.1002/mds. 10438

\section{국문초록}

한국어판 파킨슨병 삶의 질 축약형 도구의 신뢰도와 타당도 김세현'·박혜자.·박민정··김현숙4

1단국대학교 대학원 교수, ${ }^{2}$ 차의과학대학교 간호대학 교수, ${ }^{3}$ 차의과학대학교 분당차병원 간호국 교수, ${ }^{4}$ 차의과학대학교 분당차병원 신경과 교수

목적: 파킨슨병 환자를 위한 건강관리 전략을 개발하고 증진하는데 건강 관련 삶의 질 측정은 매우 중요하다. 8 개의 항목으로 구성된 파킨슨병 삶의 질 도구(PDQ-8)는 39개 항목으로 개발된 파킨슨병 삶의 질 도구(PDQ-39)의 축약형으로 파킨슨병 환자의 건강상태를 측정하는데 유용하다. 본 연구는 한국어판 축약형 파킨슨병 삶의 질 측정도구의 신뢰도와 타당도를 확인하고자 한다.

방법: 80명의 파킨슨병 환자가 자가보고형으로 PDQ-39와 PDQ-8 설문지에 무작위 순위로 응답하였다. PDQ-39 응답점수와 PDQ-8 응 답점수를 이용하여 건강상태지수를 환산하였다. 파킨슨병 중증도 점수, 운동능력, 간이정신건강, 몬트리올 인지평가, 임상치매척도, 국 제치매척도를 이용하여 임상지표 자료를 수집하였다.

결과: 축약형 파킨슨병 삶의 질 도구의 천장효과 $2.5 \%$ 와 바닥효과 $1.3 \%$ 는 적절하였고 내적일관성 신뢰도 계수 $(\alpha=0.88)$, 문항-총점 상관 계수 $(0.48-0.77)$, 카파상관계수 0.53 은 적절하였다. 축약형 파킨슨병 삶의 질 문항은 하나의 요인에 적재되었고(고윳값 $=4.35$, 분산설명력 $=54.51 \%)$ 요인적재량은 만족되었으며 $(0.585-0.847)$, 확인적요인분석의 모형은 적합하였다(GFI $0.932, \mathrm{NFI}=0.914, \mathrm{TLI}=0.973, \mathrm{IFI}=0.981$, $\mathrm{CFI}=0.981, \mathrm{RMSEA}=0.056)$. 축약형 파킨슨병 삶의 질 도구는 문항 간 유의한 상관관계를 보였고 $(p<0.05), \mathrm{PDQ}-8$ 건강상태지수는 PDQ-39 건강상태지수와 유의한 상관관계를 보여 $(\mathrm{r}=0.91, p<0.001)$ 수렴타당도는 만족되었다. 축약형 파킨슨병 삶의 질의 건강상태 지 수는 레보도파민 복용량 $(\mathrm{r}=0.28, p=0.028)$, 파킨슨병 중증도 $(\mathrm{r}=0.44, p=0.001)$, 운동능력 $(\mathrm{r}=0.45, p=0.007)$, 간이정신검사 $(\mathrm{r}=-0.28$, $p=0.047)$, 몬트리올 인지평가 $(\mathrm{r}=-0.49, p=0.006)$, 임상치매척도 $(\mathrm{r}=0.33, p=0.025)$, 국제치매척도 $(\mathrm{r}=0.40, p=0.007)$ 와 유의한 상관관계를 보여 준거타당도를 만족하였다.

결론: 한국어판 축약형 파킨슨병 삶의 질 도구는 파킨슨병 환자가 지각하는 건강상태를 측정할 수 있는 신뢰도와 타당도가 높은 도구 로 간호실무와 연구 수행에 유용한 도구로 사용할 수 있을 것이다.

주제어: 파킨슨병, 삶의 질, 신뢰도, 타당도 